\title{
Tvilsom effekt av renal denervering
}

\author{
Renal denervering er blitt fremstilt som en ny behandling av terapiresistent hypertensjon. Etter at det er \\ utført flere prospektive, randomiserte, kontrollerte og til dels blindede studier, har resultatene av behand- \\ lingen gått fra «lovende» til «tvilsom effekt». Metoden har per i dag ingen plass i behandlingen av terapi- \\ resistent hypertensjon.
}

Til tross for intens blodtrykksbehandling er det mange som ikke når behandlingsmålet og hevdes å ha terapiresistent hypertensjon. Dette defineres som blodtrykk $>140 / 90$ mm Hg på tross av inntak av minst tre antihypertensive medikamenter fra forskjellige klasser i høyeste tolererte doser, der minst ett av medikamentene er et diuretikum (1).

Renal denervering (RDN) er de siste årene av flere internasjonale forskningsgrupper (2-4) blitt fremstilt som et alternativ for denne pasientgruppen. Behandlingen går ut på at man ved hjelp av perkutan endovaskulær teknikk utfører ablasjon av sympatiske nerver som ligger i nyrearterieveggen. Som regel benyttes et kateter som formidler radiofrekvensenergi. Det føres inn via a. femoralis til nyrearteriene. Første beskrivelse av renal denervering utført hos mennesker kom i 2009 (2) og fikk svært mye oppmerksomhet. Dette la grunnlaget for kliniske studier, blant annet SYMPLICITY-studiene $(3,4)$. De to første SYMPLICITY-studiene er omtalt i en oversiktsartikkel skrevet av noen av oss i Tidsskriftet nr. 1/2014 (5), den siste vil bli omtalt her.

\section{Nye randomiserte studier}

Vår forskningsgruppe var den første til å undersøke effekter av renal denervering hos pasienter med dokumentert terapiresistent hypertensjon (6). Studien inkluderte seks pasienter med systolisk kontorblodtrykk $>140 \mathrm{~mm} \mathrm{Hg}$ og ambulatorisk systolisk blodtrykk $>135 \mathrm{~mm} \mathrm{Hg}$ umiddelbart etter observert inntak av forskrevet antihypertensiv medikasjon. 12 pasienter ble ekskludert fordi de ikke hadde terapiresistent hypertensjon. Blodtrykksmålinger ble gjort etter én, tre og seks måneder. Det var ingen sikker endring i verken kontorblodtrykk eller ambulatorisk blodtrykk hos de seks pasientene etter utført behandling.

I en senere prospektiv, randomisert og kontrollert studie - Oslo RDN-studien, også utført av vår forskningsgruppe - ble behandlingen sammenliknet med impedanskardiografisk veiledet optimalisert medikamentell behandling, hvor medikamentjusteringer for bedre blodtrykkskontroll gjøres etter ikke-invasive hemodynamiske målinger av blodvolum, perifer karmotstand og hjertets pumpekraft. Kriterier for inklusjon var de samme som i forrige studie (6).

65 pasienter ble utredet og 19 inkludert. I gruppen med optimalisert medikamentell behandling var reduksjonen av systolisk og diastolisk blodtrykk etter seks måneder signifikant. I gruppen som hadde fått renal denervering var det ikke signifikant endring i blodtrykk. Ved sammenlikning av gruppene etter seks måneder var det signifikant lavere systolisk og diastolisk kontorblodtrykk i gruppen med optimalisert medikamentbehandling - p-verdi henholdsvis 0,002 og 0,004 . Det var bare to pasienter i medikamentendringsgruppen som ikke oppnådde blodtrykkskontroll, mens det i gruppen som hadde fått renal denervering fortsatt var terapisvikt hos alle etter seks måneder.

Endringen i ambulatorisk blodtrykk hos pasientene i gruppen som fikk medikamentell behandling var signifikant. Etter seks måneder var det også i gruppen som hadde fătt renal denervering signifikant redusert blodtrykk. Ved sammenlikning av de to

\section{«Livsstilsendringer og farmakologisk terapi er fortsatt vår beste antihypertensive behandling»}

gruppene var det signifikant lavere ambulatorisk blodtrykk i gruppen som fikk optimalisert medikamentell behandling enn i den andre gruppen. Resultatet var det samme for reduksjon i systolisk blodtrykk etter tre måneder, men ikke etter seks måneder.

Den tredje og siste SYMPLICITY-studien ble publisert ultimo mars 2014. Bhatt og medarbeider gjorde en prospektiv, randomisert, enkeltblindet og simuleringskontrollert (sham) studie av den blodtrykkssenkende effekten av renal denervering $(8,9)$. Studien ble utført for å utfylle de første kliniske studiene (2-4), som hadde betydelige metodologiske svakheter. Fordelingen mellom de to gruppene var $2: 1$, henholdsvis 364 og 171 pasienter. Inklusjonskriteriene var terapiresistent hypertensjon og systolisk kontorblodtrykk $\geq 160 \mathrm{~mm} \mathrm{Hg}$ samt ambulatorisk systolisk blodtrykk $>135 \mathrm{~mm} \mathrm{Hg}$.

Etter seks måneder var det en reduksjon i systolisk kontorblodtrykk i gruppen som hadde fått renal denervering på $14 \mathrm{~mm} \mathrm{Hg}$, mot en reduksjon på 11 mm Hg i kontroll- gruppen. Forskjellen i reduksjon mellom gruppene var ikke-signifikant. Reduksjonen i ambulatorisk blodtrykk for gruppen som hadde fătt renal denervering og kontrollgruppen var henholdsvis $6 \mathrm{~mm} \mathrm{Hg}$ og $4 \mathrm{~mm}$ $\mathrm{Hg}$, og forskjellen i reduksjon var ikke-signifikant.

\section{Ingen plass i rutinebehandling}

De første funnene fra SYMPLICITY HTN-1og HTN-2-studiene $(3,4)$ skapte stor begeistring for renal denervering. Det er nok flere svar på hvorfor disse viste så store blodtrykkssenkende effekter. I første omgang er det nærliggende å trekke frem placeboeffekten og regresjon til middelverdien. Etter vårt syn burde disse studiene kun betraktes som hypotesegenererende (5).

Man må skille klart mellom ekte terapiresistent hypertensjon og dårlig etterlevelse av antihypertensiv behandling. Det er vist at prevalensen av delvis eller fullstendig manglende etterlevelse er høyest hos pasienter henvist for renal denervering (10). Det reduserte blodtrykket som ble funnet $i$ de to første SYMPLICITY-studiene $(3,4)$ har nok vært reelt, men sannsynligvis forårsaket av bedret medikamentetterlevelse i forløpet av studiene, såkalt Hawthorneeffekt, og ikke av renal denervering.

Våre arbeider $(6,7)$ har således hatt sin hovedstyrke i pasientseleksjonen, der observasjon av medikamentinntaket før kvalifiserende ambulatorisk blodtrykksmåling var sentralt. Hos slike pasienter med dokumentert terapiresistent hypertensjon hadde renal denervering ingen sikker effekt på blodtrykket $(6,7)$, mens effekten i de første SYMPLICITY-studiene $(3,4)$ lett kan forklares av bedret medikamentetterlevelse i forløpet av studiene. Den tredje SYMPLICITY-studien $(8,9)$, med simuleringskontroll, nøytraliserte placebo- og Hawthorne-effektene. Denne studien viste ingen sikker effekt av renal denervering og setter derfor resultatene av SYMPLICITY HTN-1- og HTN-2-studiene i et nytt lys (3, 4) samt understøttet resultatene av våre studier $(6,7)$. SYMPLICITY HTN-3-studien styrker mistanken om at placebo- og Hawthorne-effekten spilte en stor rolle for resultatene man tidligere så av renal denervering ved terapiresistent hypertensjon.

På det europeiske og internasjonale hypertensjonsmøtet i Aten i juni 2014 ble det presentert ytterligere randomisert og kontrollert forskning på renal denervering ved terapiresistent hypertensjon. Widimsky og 
medarbeidere har gjort en studie med 106 pasienter randomisert til renal denervering eller fortsatt farmakologisk terapi (11). Denne viste ingen signifikant blodtrykksenkende effekt av inngrepet. Azizi og medarbeidere har gjort en liknende studie med 106 pasienter, den viste en svak blodtrykkssenkende effekt av renal denervering (12). Disse resultatene samsvarer med resultatet av våre arbeider samt SYMPLICITY HTN-3.

På tross av resultatene som er presentert over, diskuteres renal denervering fortsatt meget intenst $\mathrm{i}$ internasjonale fora, og man prøver å finne årsaker til fraværet av gode resultater i de seneste studiene (13). Argumentene som trekkes frem er blant annet mulig fravær av fullstendig ablasjon, amerikanske operatørers manglende erfaring og

\section{«Kommersielle krefter har større innflytelse enn vi liker å tro»}

inklusjon av for mange afroamerikanske pasienter. Vi har vanskelig for å se at dette er slagkraftige argumenter ut fra prosedyrens krav til tekniske ferdigheter og studienes design. Vi ser heller ingen grunn til å tro at slike forhold svekker en stor randomisert og blindet studie $(8,9)$, i lys av de store svakhetene ved de første studiene $(3,4)$ som er påpekt over.

Medisinen skal være et kunnskapsbasert fagfelt. Likevel kan det virke som om kommersielle krefter har større innflytelse enn vi liker å tro. At minst 20000 personer (14) har fått utført ablasjon av nyrenerver på tynt grunnlag, bevitner dette. Slik vi ser det, har ikke renal denervering noen plass i den rutinemessige behandling av terapiresistent hypertensjon, og praksisen bør utgå. Livsstilsendringer og farmakologisk terapi er fortsatt vår beste antihypertensive behandling. Eventuell videre forskning på renal denervering bør dreie seg om å finne potensielle, men sjeldne, respondere på prosedyren, men dette krever tålmodig langtidsarbeid og må ikke gå på bekostning av optimalisert medikamentell behandling.
Julian Eek Mariampillai

Fadl Elmula Mohamed Fadl Elmula

Pavel Hoffmann

Heidi Sørensen

Aud Høieggen

Sverre E. Kjeldsen

s.e.kjeldsen@medisin.uio.no

Julian Eek Mariampillai (f. 1992) er medisinstudent ved Universitetet i Oslo.

Forfatter har fylt ut ICMJE-skjemaet og oppgir ingen interessekonflikter.

Fadl Elmula Mohamed Fadl Elmula (f. 1972) er spesialist i indremedisin og i kardiologi, overlege ved Generell indremedisinsk avdeling, Oslo universitetssykehus, Ullevål, og stipendiat ved Institutt for klinisk medisin, Universitetet i Oslo.

Forfatter har fylt ut ICMJE-skjemaet og oppgir følgende interessekonflikter: Han har mottatt forelesningshonorar fra Medtronic og Hemo Sapiens.

Pavel Hoffmann (f. 1958) er dr.med., spesialist i radiologi og overlege ved Seksjon for intervensjonskardiologi, Avdeling for kardiologi, Hjerte-, lunge- og karklinikken, Oslo universitetssykehus, Ullevål.

Forfatter har fylt ut ICMJE-skjemaet og oppgir ingen interessekonflikter.

Heidi Sørensen (f. 1989) er medisinstudent ved Universitetet i Oslo.

Forfatter har fylt ut ICMJE-skjemaet og oppgir ingen interessekonflikter.

Aud Høieggen (f. 1956) er dr.med., spesialist i indremedisin og i nyresykdommer, overlege ved Nyremedisinsk avdeling, Oslo universitetssykehus, Ullevål, og førsteamanuensis ved Institutt for klinisk medisin, Universitetet i Oslo. Forfatter har fylt ut ICMJE-skjemaet og oppgir ingen interessekonflikter.

Sverre E. Kjeldsen (f. 1953) er dr.med., spesialist $\mathrm{i}$ indremedisin og i kardiologi, overlege ved Hjertemedisinsk avdeling, Oslo universitetssykehus, Ullevål, og professor ved Institutt for klinisk medisin, Universitetet i Oslo.

Forfatter har fylt ut ICMJE-skjemaet og oppgir følgende interessekonflikter: Han har mottatt honorar for forelesninger/rådgivning fra AZ, Bayer, Medtronic, Merck, Novartis, Serodus og Takeda, royalty fra Gyldendal og forskningsmidler fra AZ, Hemo Saphiens og Pronova.

\section{Litteratur}

1. Calhoun DA, Jones D, Textor S et al. Resistant hypertension: diagnosis, evaluation, and treatment: a scientific statement from the American Heart Association Professional Education Committee of the Council for High Blood Pressure Research. Circulation 2008; 117: e510-26.

2. Schlaich MP, Sobotka PA, Krum H et al. Renal sympathetic-nerve ablation for uncontrolled hypertension. N Engl J Med 2009; 361: 932-4.

3. Esler MD, Krum H, Sobotka PA et al. Renal sympathetic denervation in patients with treatmentresistant hypertension (The Symplicity HTN-2 Trial): a randomised controlled trial. Lancet 2010; 376: 1903-9

4. Symplicity HTN-1 Investigators. Catheter-based renal sympathetic denervation for resistant hypertension: durability of blood pressure reduction out to 24 months. Hypertension 2011: 57: 911-7.

5. Sørensen H. Fadl Elmula FE, Kjeldsen SE et al. Renal sympatisk denervering ved terapiresistent hypertensjon. Tidsskr Nor Legeforen 2014; 134: 32-6.

6. Fadl Elmula FE, Hoffmann P, Fossum E et al. Renal sympathetic denervation in patients with treatment-resistant hypertension after witnessed intake of medication before qualifying ambulatory blood pressure. Hypertension 2013: 62: 526-32.

7. Fadl Elmula FE, Hoffmann P, Larstorp AC et al. Adjusted drug treatment is superior to renal sympathetic denervation in patients with true treatment-resistant hypertension. Hypertension 2014 63: $991-9$

8. Bhatt DL, Kandzari DE, O'Neill WW et al. A controlled trial of renal denervation for resistant hypertension. N Engl J Med 2014; 370: 1393-401.

9. Kandzari DE, Bhatt DL, Sobotka PA et al. Catheterbased renal denervation for resistant hypertension: rationale and design of the SYMPLICITY HTN-3 Trial. Clin Cardiol 2012; 35: 528-35.

10. Tomaszewski M, White $C$, Patel $P$ et al. High rates of non-adherence to antihypertensive treatment revealed by high-performance liquid chromatography-tandem mass spectrometry (HP LC-MS/ MS) urine analysis. Heart 2014; 100: 855-61.

11. Widimsky J, Rosa J, Tousek P et al. Renal denervation versus intensified medical treatment including spironolactone in patients with true resistant hypertension: 6-months results of multicenter randomized Prague. J Hypertens 2014; 32: e87.

12. Azizi M. Monge M. Pereira $\mathrm{H}$ et al. The French DENER-HTN trial: renal denervation + standardized antihypertensive treatment vs. standardized antihypertensive treatment alone in patients with resistant hypertension. J Hypertens 2014; 32: e89.

13. Bhatt DL. What does the future hold for renal denervation? Eur Heart J 2014; 35: 1695-6.

14. Persu A, Jin Y, Fadl Elmula FE et al. Renal denervation after Symplicity HTN-3: an update. Curr Hypertens Rep 2014; 16: 460-9.

Mottatt 24.7. 2014, første revisjon innsendt 20.8 . 2014, godkjent 26.8. 2014. Redaktør: Hanne Støre Valeur.

Publisert først på nett. 